\begin{tabular}{l|l|l|l}
$\begin{array}{l}\text { Case Reports in } \\
\text { Deillati. }\end{array}$ & $\begin{array}{l}\text { Case Rep Dermatol 2011;3:49-54 } \\
\text { DOI: } 10.1159 / 000325068\end{array}$ & $\begin{array}{l}\text { Published online: } \\
\text { February 25, 2011 }\end{array}$ & $\begin{array}{l}\text { O 2011 S. Karger AG, Basel } \\
\text { ISSN 1662-6567 } \\
\text { www.karger.com/cde }\end{array}$ \\
\hline
\end{tabular}

\title{
Chronic Actinic Dermatitis with Leonine Facies and latrogenic Adrenal Insufficiency Successfully Treated with Topical Tacrolimus
}

\author{
Ploysyne Busaracome Penpun Wattanakrai \\ Natta Rajatanavin \\ Division of Dermatology, Department of Medicine, Ramathibodi Hospital, \\ Mahidol University, Bangkok, Thailand
}

\section{Key Words}

Chronic actinic dermatitis · Adrenal insufficiency · Topical tacrolimus

\begin{abstract}
Chronic actinic dermatitis is a chronic photosensitivity disorder characterized by severe eczematous lesions on sun-exposed skin areas. We report a case of chronic actinic dermatitis presenting with leonine facies and secondary adrenal insufficiency, which was successfully treated with topical tacrolimus. The facial lesions dramatically improved after sun avoidance and topical tacrolimus application. After almost 20 years of oral corticosteroid therapy complicated with secondary adrenal insufficiency, we were able to switch treatment from systemic corticosteroids to topical tacrolimus to control the patient's symptoms.
\end{abstract}

\section{Introduction}

Chronic actinic dermatitis (CAD) is a severe photosensitivity disease induced by UVB, UVA and occasionally visible light. This idiopathic photodermatosis typically affects elderly men. Clinical manifestations include eczematous lesions, infiltrated plaques and pruritic erythematous papules, which develop on light-exposed areas, particularly the face, neck and upper chest [1]. The severity of the disease in each individual depends on the degree of photosensitivity, ranging from chronic eczematous lesions to erythroderma. Histopathological findings usually show eczematous appearance but sometimes may resemble cutaneous lymphoma [2]. The diagnosis of CAD is based on the following 3 criteria: persistent photodermatitis without history of exposure to known 


\begin{tabular}{|c|c|c|c|}
\hline $\begin{array}{l}\text { Cose Reports in } \\
\text { in: }\end{array}$ & $\begin{array}{l}\text { Case Rep Dermatol 2011;3:49-54 } \\
\text { DOI: } \underline{10.1159 / 000325068}\end{array}$ & $\begin{array}{l}\text { Published online: } \\
\text { February } 25,2011\end{array}$ & $\begin{array}{l}\text { (c) } 2011 \text { S. Karger AG, Basel } \\
\text { ISSN } 1662-6567 \\
\text { www.karger.com/cde }\end{array}$ \\
\hline
\end{tabular}

photosensitizers, abnormal delayed erythemal responses to UVB and/or UVA and/or visible light, and a histological finding consistent with photodermatitis [3]. The pathophysiology of CAD remains unclear, but current evidence suggests a delayed-type hypersensitivity reaction to endogenous photo-induced allergens. Several treatment modalities have been proposed to induce long-term remission, such as systemic corticosteroid, azathioprine, and PUVA; however, the use of these treatment options has limited efficacy and is associated with severe side effects.

\section{Case Report}

A 37-year-old male farmer presented to our hospital with a 22 -year history of itchy indurated facial erythematous plaques. He has been treated with oral corticosteroids (prednisolone 30-60 mg/day) with only temporary improvement. He had no history of exposure to any chemicals, plants, or perfumes. Additionally, he had no known underlying disease and there was no family history of similar skin conditions.

Physical examination showed huge indurated lichenified erythematous infiltrative plaques on his forehead, nose, and both cheeks (fig. 1), and there were discrete erythematous papules on both forearms. A skin biopsy from a lesion of the left cheek was obtained and stained with HE. The biopsy specimen consisted of mounds of parakeratosis, spongiosis and epidermal hyperplasia associated with dense superficial inflammatory cell infiltrates, mainly lymphocytes, in the thickened papillary dermis. Routine laboratory findings were normal, except for a very low morning serum cortisol level $(<1 \mu \mathrm{g} / \mathrm{dl})$. Antinuclear antibody and anti-HIV tests were negative. Patch and photopatch testing (including analysis of common photoallergens such as sunscreen, fragrance, and sesquiterpene lactone) revealed no contact sensitivity (table 1). Phototesting was done on uninvolved skin. The patient's minimal erythema dose to both UVA and UVB demonstrated a significantly reduced threshold for UVA $\left(3 \mathrm{~J} / \mathrm{cm}^{2}\right.$; reference value: $\left.30 \mathrm{~J} / \mathrm{cm}^{2}\right)$ and UVB-induced erythema $\left(12 \mathrm{~mJ} / \mathrm{cm}^{2}\right.$; reference value: $\left.45-60 \mathrm{~mJ} / \mathrm{cm}^{2}\right)$ for his skin phototype IV (fig. 2). After 4 months of topical tacrolimus therapy and sun avoidance by using sunscreen and wearing opaque clothes and a broad-brimmed hat, there was a significant improvement of his facial lesions (fig. 3 ). Remission of CAD could be maintained by topical tacrolimus, and the secondary adrenal insufficiency induced by exogenous corticosteroid therapy recovered after discontinuation of oral steroids.

\section{Discussion}

In this case, $\mathrm{CAD}$ with extensive leonine facies was successfully treated with $0.1 \%$ tacrolimus ointment twice daily. A clinically significant improvement of all lesions was observed after 4 months. There was no adverse effect except for a mild transient burning sensation during the first few treatment days. Tacrolimus is an immunosuppressive macrolide antibiotic, which inhibits calcineurin and suppresses the activation of antigenspecific $\mathrm{T}$ cells and the release of inflammatory cytokines, such as interleukin 2 and tumor necrosis factor [4]. T cell activation may be important for the pathogenesis of CAD. This hypothesis is supported by both the fact that the infiltrating cells are predominantly $\mathrm{T}$ cells and the immunological effects of tacrolimus [5]. This advocates the use of topical tacrolimus as maintenance therapy and to prevent recurrence. After a follow-up period of 1 year with strict sun protection and maintenance therapy with topical tacrolimus once daily, the patient eventually achieved remission. Although there have been several reports of CAD cases successfully treated with topical tacrolimus [5-8], this is the first case with severe and extensive leonine facies, which were uncontrolled despite 20 years of oral corticosteroid use, which in contrary induced secondary adrenal insufficiency as adverse 
effect. After remission, the oral corticosteroid was successfully tapered and discontinued within 6 months; thereafter, the morning serum cortisol level returned to a normal range.

In conclusion, this case demonstrates for the first time that topical tacrolimus might be an appropriate topical treatment with minimal side effects to induce and maintain remission in severe CAD cases.

\section{Disclosure Statement}

The authors declare that they have no conflict of interest. 


\begin{tabular}{|c|c|c|c|}
\hline Cose Reports in & $\begin{array}{l}\text { Case Rep Dermatol 2011;3:49-54 } \\
\text { DOI: } \underline{10.1159 / 000325068}\end{array}$ & $\begin{array}{l}\text { Published online: } \\
\text { February 25, } 2011\end{array}$ & $\begin{array}{l}\text { (c) } 2011 \text { S. Karger AG, Basel } \\
\text { ISSN } 1662-6567 \\
\text { www.karger.com/cde }\end{array}$ \\
\hline
\end{tabular}

Table 1. Photopatch test form

\begin{tabular}{lllllll}
\hline $\begin{array}{l}\text { Test } \\
\text { No. }\end{array}$ & Photopatch series & $\frac{48 \mathrm{~h}}{\mathrm{NR} \mathrm{R}}$ & & $\frac{72 \mathrm{~h}}{\mathrm{NR} \mathrm{R}}$ & $\frac{96 \mathrm{~h}}{\mathrm{NR} \mathrm{R}}$ \\
\hline
\end{tabular}

SU1 4-tert-Butyl-4'-methoxy-dibenzoylmethane (Parsol 1789) 2.0 pet B029

SU2 4-Aminobenzoic acid (PABA) 5.0 pet A006

SU3 4-Isopropyl-dibenzoylmethane (Eusolex 8020) 2.0 pet I005

SU4 3-(4-Methylbenzyliden) camphor (Eusolex 6300) 2.0 pet $\mathrm{M} 024$

SU5 2-Ethylhexyl-4-dimethylaminobenzoate (Eusolex 6007, Escalol 507) 2.0 pet E018

SU6 2-Hydroxy-4-methoxybenzophenone (Eusolex 4360, Escalol 567, Oxybenzone) 2.0 pet $\mathrm{H} 014$

SU7 2-Ethylhexyl-4-methoxycinnamate (Parsol MCX, Escalo 557) 2.0 pet E019

SU8 2-Hydroxy-methoxymethylbenzophenone (Mexenone) 2.0 pet $\mathrm{H} 020$

SU9 2-Phenylbenzimidazol-5-sulfonic acid (Eusolex 232, Novantisol)

SU10 2-Hydroxy-4-methoxybenzophenon-5-sulfonic acid (Sulisobenxone, Uvinyl MS-40,

Benzophenone 4) 5.0 pet $\mathrm{H} 023$

SU11 Trichlorcarbanilide (TCC) 1.0 pet T013

SU12 Tribromsalicylanilide (TBS) 1.0 pet T012

SU13 Musk ambrette 1.0 pet M017

SU14 6-Methylcoumarine (6-MC) 1.0 pet M010

SU15 Bithionol 1.0 pet B014

SU16 Wood mix (pine, spruce, birch, teak) 20.0 pet Mx09

SU17 Tetrachlorsalicylanilide (TCS) 0.1 pet T001

SU18 Hexachlorophene 1.0 pet $\mathrm{H} 001$

SU19 Diphenhydramine hydrochloride 1.0 pet D021

SU20 Perfume mix 6.0 pet Mx08

SU21 Diallyldisulfide 1.0 pet D048

SU22 Chrysanthemum cinerariaefolium

(Pyrethrum) 1.0 pet C031

SU23 Sesquiterpene lactone mix 0.1 pet Mx18

SU24 Lichen acid mix 0.3 pet Mx15

SU25 Sulfanilamide 5.0 pet S010

SU26 T026 Thiourea $0.1 \%$ pet

SU27 Quinidire 1\% pet

SU28 Naproxen 5\% pet

SU29 Ibuprofe 5\% pet

SU30 Diclofenac $1 \%$ pet

SU31 Ketoprofen $2.5 \%$ pet

SU32 Balsam Peru 25.0 pet B001

SU33 2-tert-Butyl-4-methoxyphenol (BHA) 2.0 pet $\mathrm{B} 022$

SU34 Chlorhexidine digluconate 0.5 aq C005

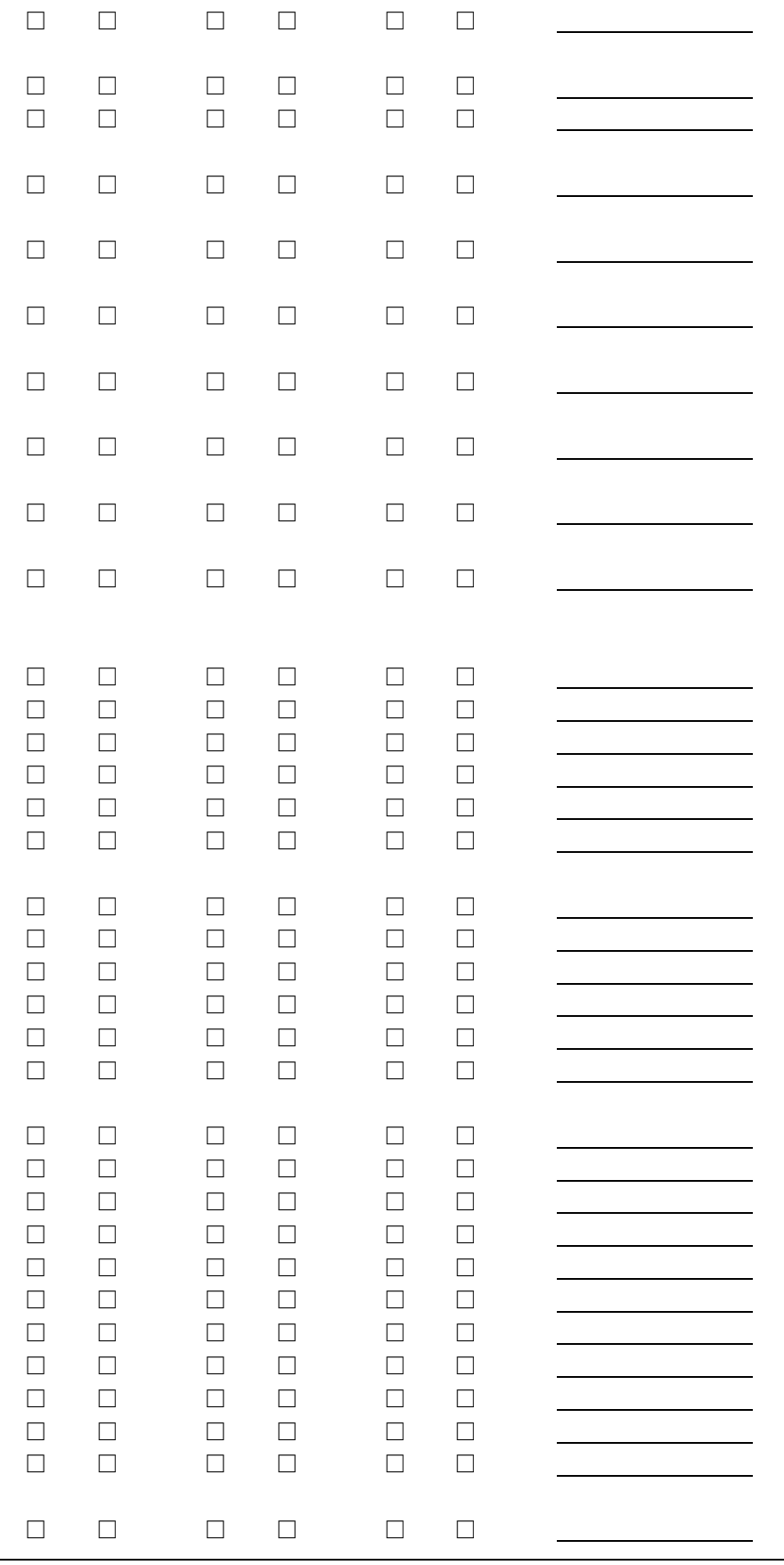




\begin{tabular}{|c|c|c|c|}
\hline $\begin{array}{l}\text { Case Reports in } \\
\text { isilalinil }\end{array}$ & $\begin{array}{l}\text { Case Rep Dermatol 2011;3:49-54 } \\
\text { DOI: } \underline{\text { 10.1159/000325068 }}\end{array}$ & $\begin{array}{l}\text { Published online: } \\
\text { February } 25,2011\end{array}$ & $\begin{array}{l}\text { ( ) } 2011 \text { S. Karger AG, Basel } \\
\text { ISSN } 1662-6567 \\
\text { www.karger.com/cde }\end{array}$ \\
\hline
\end{tabular}

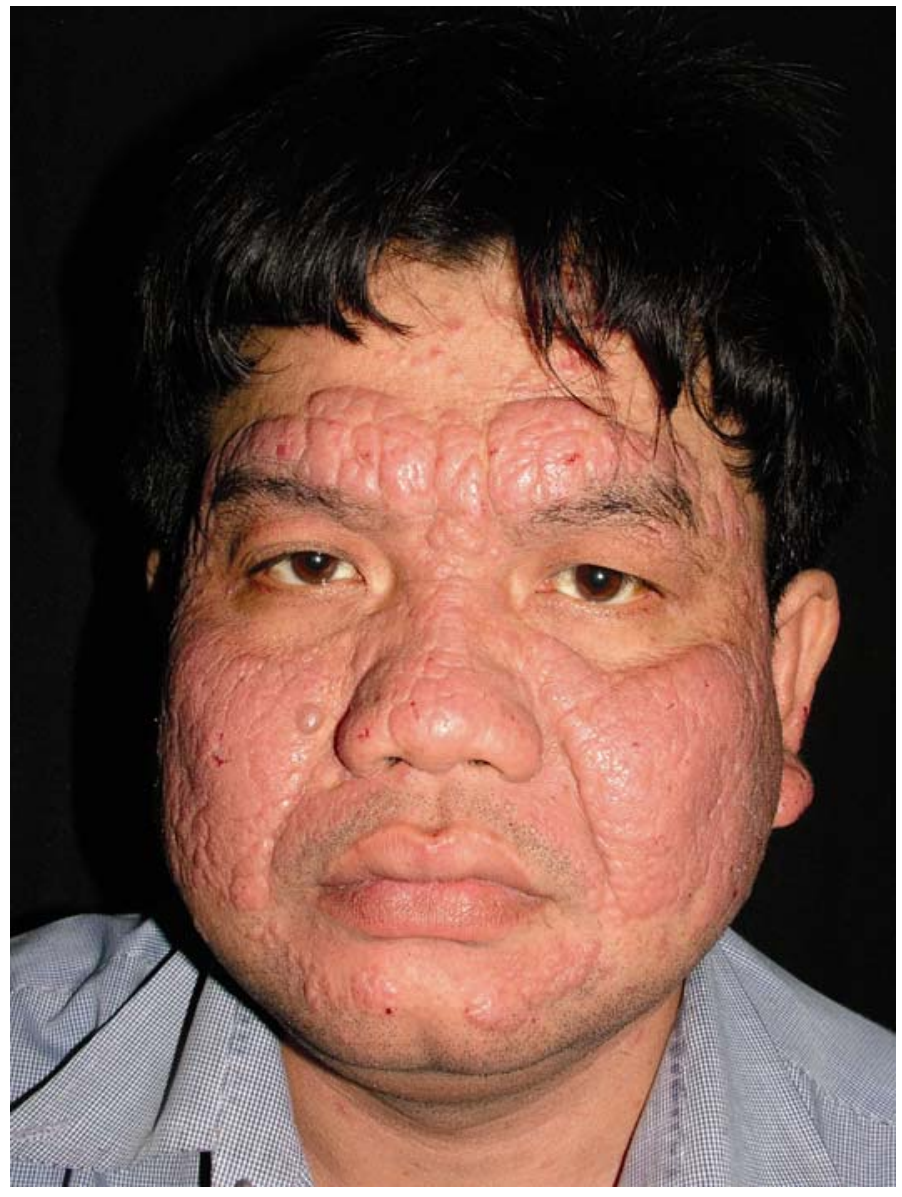

Fig. 1. Before treatment.

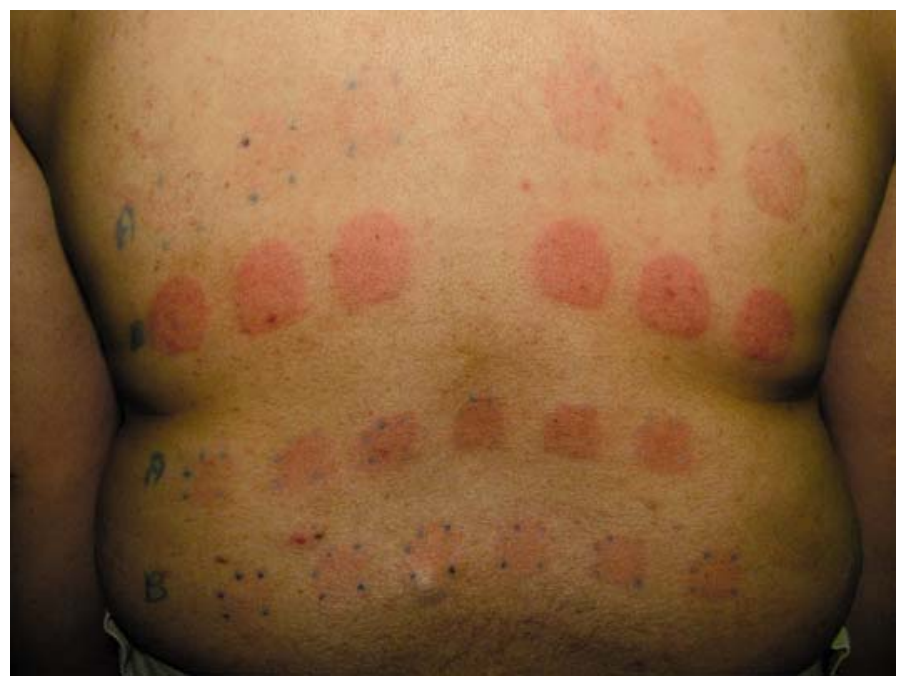

Fig. 2. Reduced threshold for UVA and UVB. 


\begin{tabular}{l|l|l|l} 
Case Reports in & $\begin{array}{l}\text { Case Rep Dermatol 2011;3:49-54 } \\
\text { DOI: } 10.1159 / 000325068\end{array}$ & $\begin{array}{l}\text { Published online: } \\
\text { February 25, 2011 }\end{array}$ & $\begin{array}{l}\text { ISSN 1662-6567 } \\
\text { www.karger.com/cde }\end{array}$ \\
\hline
\end{tabular}

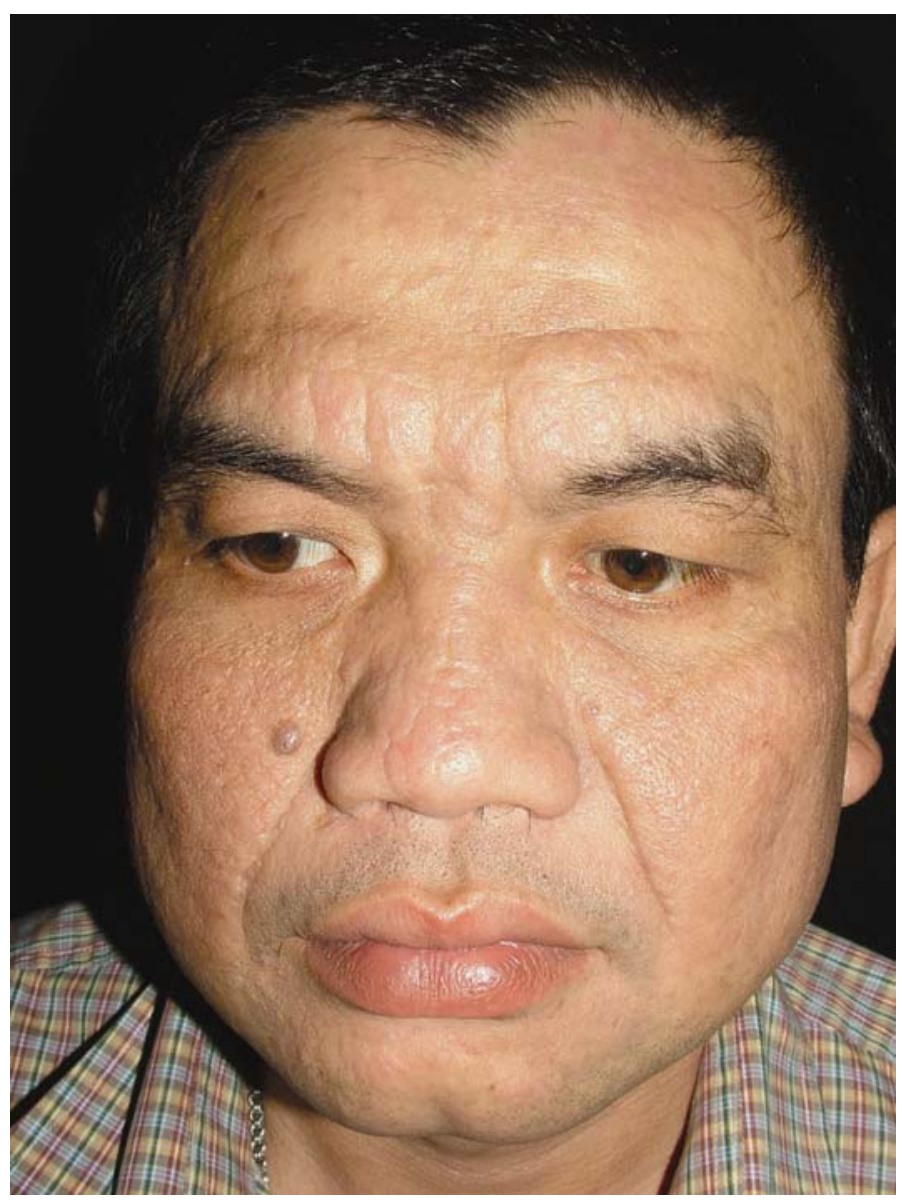

Fig. 3. After 6 months of treatment.

\section{References}

- 1 Hawk JLM, Magnus IA: Chronic actinic dermatitis - an idiopathic photosensitivity syndrome including actinic reticuloid and photosensitive eczema. Br J Dermatol 1979;101(suppl 17):24.

2 Roelandts R: Chronic actinic dermatitis. J Am Acad Dermatol 1993;28:240-249.

-3 Yap LM, Foley P, Crouch R, Baker C: Chronic actinic dermatitis: a retrospective analysis of 44 cases referred to an Australian photobiology clinic. Australas J Dermatol 2003;44:256-262.

4 Zabawski EJ, Costner M, Cohen J, Cockerell CJ: Tacrolimus: pharmacology and therapeutic uses in dermatology. Int J Dermatol 2000;39:721-727.

5 Uetsu N, Okamoto H, Fujii K, Doi R, Horio T: Treatment of chronic actinic dermatitis with tacrolimus ointment. J Am Acad Dermatol 2002;47:881-884.

6 Abe R, Shimizu T, Tsuji A, Matsumura T, Shimizu H: Severe refractory chronic actinic dermatitis successfully treated with tacrolimus ointment. Br J Dermatol 2002;147:1273-1275.

7 Evans AV, Palmer RA, Hawk JLM: Erythrodermic chronic actinic dermatitis responding only to topical tacrolimus. Photodermatol Photoimmunol Photomed 2004;20:59-61.

8 Schuster C, Zepter K, Kempf W, Dummer R: Successful treatment of recalcitrant chronic actinic dermatitis with tacrolimus. Dermatology 2004;209:325-328. 